\title{
Fluid and metal sources in the Fäboliden hypozonal orogenic gold deposit, Sweden
}

\author{
Glenn Bark ${ }^{1} \cdot$ Adrian J. Boyce $^{2} \cdot$ Anthony E. Fallick $^{2} \cdot$ Pär Weihed $^{1}$ \\ Received: 11 October 2019 / Accepted: 13 March 2020 / Published online: 4 April 2020 \\ (C) The Author(s) 2020
}

\begin{abstract}
To model the formation of orogenic gold deposits, in a global perspective, it is important to understand the ore-forming conditions not only for deposits hosted in greenschist facies rocks but also in amphibolite facies. The Paleoproterozoic Fäboliden deposit in northern Sweden belongs to the globally rare hypozonal group of orogenic gold deposits and, as such, constitutes a key addition to the understanding of amphibolite facies orogenic gold deposits. The Fäboliden deposit is characterized by auriferous arsenopyrite-rich quartz veins, hosted by amphibolite facies supracrustal rocks and controlled by a roughly N-striking shear zone. Gold is closely associated with arsenopyrite-löllingite and stibnite, and commonly found in fractures and as inclusions in the arsenopyrite-löllingite grains. The timing of mineralization is estimated from geothermometric data and field relations at c. $1.8 \mathrm{Ga}$. In order to constrain the origin of gold-bearing fluids in the Fäboliden deposit, oxygen, hydrogen, and sulfur isotope studies were undertaken. $\delta^{18} \mathrm{O}$ from quartz in veins shows a narrow range of +10.6 to $+13.1 \%$. $\delta \mathrm{D}$ from biotite ranges between -120 and $-67 \%$, with most data between -95 and $-67 \%$. $\delta^{34} \mathrm{~S}$ in arsenopyrite and pyrrhotite ranges from -0.9 and $+3.6 \%$ o and from -1.5 and $+1.9 \%$, respectively. These stable isotope data, interpreted in the context of the regional and local geology and the estimated timing of mineralization, suggest that the sulfur- and gold-bearing fluid was generated from deep-crustal sedimentary rocks during decompressional uplift, late in the orogenic evolution of the area. At the site of gold ore formation, an ${ }^{18} \mathrm{O}$-enriched magmatic fluid possibly interacted with the auriferous fluid, causing precipitation of $\mathrm{Au}$ and the formation of the Fäboliden hypozonal orogenic gold deposit.
\end{abstract}

Keywords Fluid source $\cdot$ Orogenic gold $\cdot$ Hypozonal $\cdot$ Stable isotope $\cdot$ Fennoscandia

\section{Introduction}

Gold has been one of the most sought-after commodities for thousands of years. The global historical production is estimated to be approximately 180,000 tons and about one-third of that gold comes from orogenic gold deposits (Frimmel 2008). Orogenic gold deposits are considered hydrothermal in character, having formed from gold-bearing fluids that are focused into structural traps during metamorphism and

Editorial handling: K. Kelley

Glenn Bark

Glenn.Bark@1tu.se

1 Division of Geosciences and Environmental Engineering, Luleå University of Technology, SE-971 87 Luleå, Sweden

2 Scottish Universities Environmental Research Centre (S.U.E.R.C.), East Kilbride, Glasgow, Scotland G75 0QF, UK deformation associated with accretional and collisional regimes at continental margins (Groves 1993; Groves et al. 1998, 2003; McCuaig and Kerrich 1998; Ridley et al. 2000; Hagemann and Cassidy 2000; Goldfarb et al. 2001, 2005). In recent years the Crustal Continuum model outlined during the late 1980s to early 1990s (Colvine 1989; Groves 1993) has been challenged (Phillips and Powell 2009, 2010; Tomkins and Grundy 2009). It has been suggested that orogenic gold deposits cannot form at metamorphic conditions beyond midamphibolite facies due to the inhibited fluid flow that occurs at temperatures above approximately $600-650{ }^{\circ} \mathrm{C}$, and gold deposits hosted by rocks subjected to higher metamorphic conditions are assumed to either have formed pre-peak metamorphism and subsequently overprinted by peak metamorphic conditions (Tomkins and Grundy 2009), or to have formed under retrograde PT conditions (e.g., Kolb et al. 2015). This has led to a debate on whether all orogenic gold deposits in amphibolite and granulite facies (hypozonal group) are in fact metamorphically overprinted greenschist deposits (Phillips 
and Powell 2009, 2010; Tomkins and Grundy 2009; Tomkins 2010; Kolb et al. 2015). More recently, evidence suggests that the hypozonal group is indeed post-peak metamorphic orogenic gold deposits (Kolb et al. 2015; Groves et al. 2019). In relation to this debate, the estimation of the timing of mineralization relative to peak metamorphism is vital to the understanding of the formation of orogenic gold deposits.

In northern Sweden, the Lycksele-Storuman ore province (commonly referred to as the Gold Line) is presently being explored (Fig. 1). The Gold Line is manifested by a roughly north-west trending linear anomaly of $\mathrm{Au}$ in the till overburden. During the past twenty years, a number of promising gold prospects with many features similar to orogenic gold deposits have been discovered in this area, and only a few papers have been published on the metallogeny of the Gold Line (e.g., Hart et al. 1999; Bark and Weihed 2003, 2007; Bark et al. 2007, 2013; Bark and Weihed 2012; Schlöglova et al. 2013). To date, only one of the gold deposits in the Lycksele-Storuman area, the Svartliden gold deposit (3 Mt at $4.5 \mathrm{ppm} \mathrm{Au}$; Dragon
Mining 2005) has been mined (Fig. 1). Approximately $30 \mathrm{~km}$ from the Svartliden mine is the hypozonal Fäboliden orogenic gold deposit (Bark and Weihed 2003, 2007). Fäboliden is presently the largest of the known gold prospects in the area, with previous measured and indicated mineral resources at $55 \mathrm{Mt}$ at $1.0 \mathrm{ppm} \mathrm{Au}$ (Lappland Goldminers 2012). The current owner is planning to mine the richer parts of the deposit (10.6 Mt at 3 ppm Au, Dragon Mining 2016).

The geology and geochemistry of unaltered and altered lithologies of the Fäboliden deposit is described in detail by Bark and Weihed (2007) as arsenopyrite-bearing quartz veins that occur within a high-angle shear zone in amphibolite facies rocks, mainly metagreywacke. Based on these observations, they considered the deposit to be a hypozonal orogenic gold deposit. In this contribution, stable isotope data $(\mathrm{S}, \mathrm{O}$, and $\mathrm{H})$ of the mineralized quartz veins at Fäboliden are used to characterize the oreforming fluid, to delineate potential fluid source rocks, and to put the Fäboliden deposit into the larger

Fig. 1 Bedrock map of the Lycksele-Storuman area. Coordinates in Swedish National Grid (RT90). Modified after Bark and Weihed (2007)

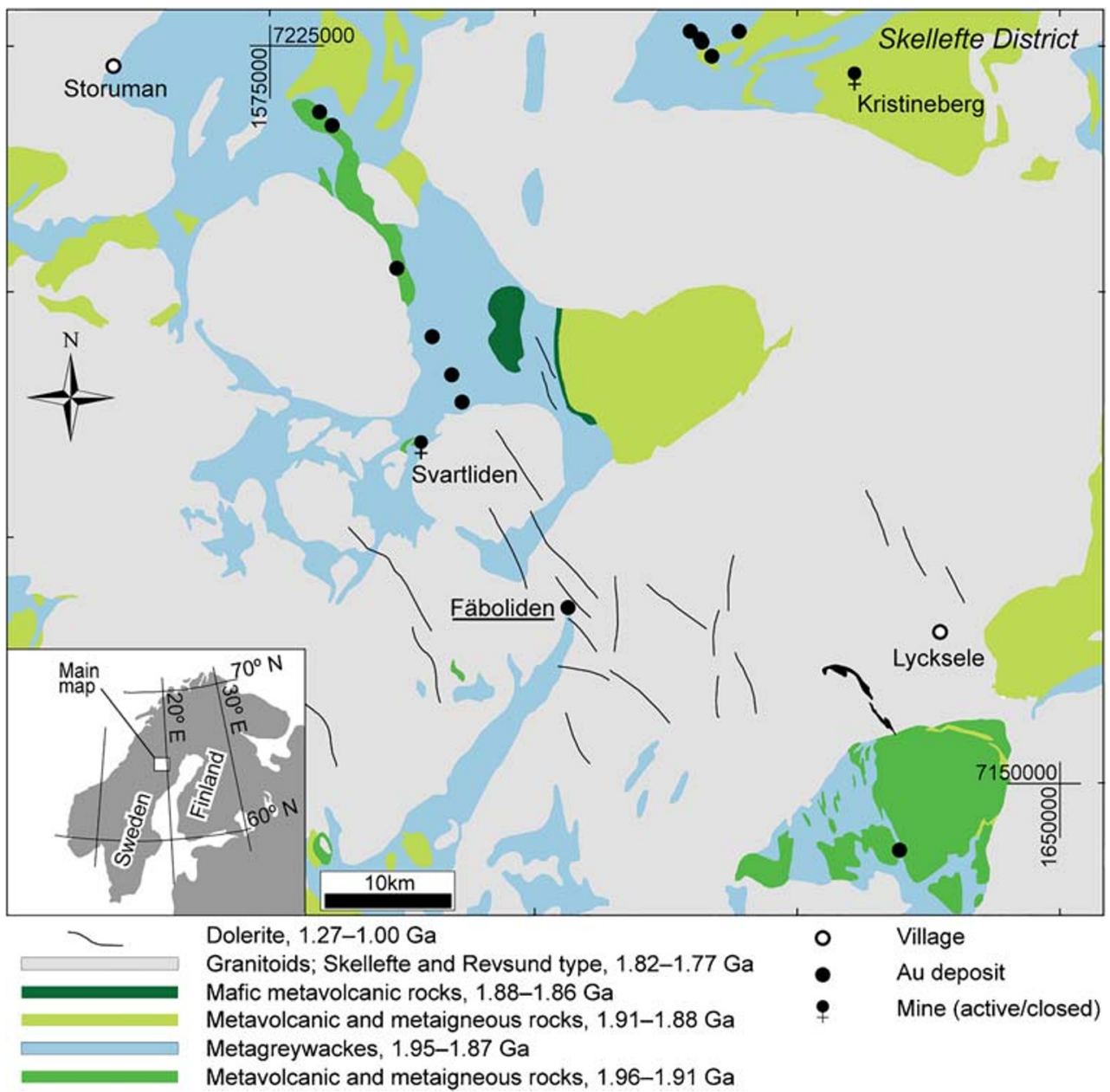


perspective in order to refine genetic models for the Fäboliden and similar deposits that will be valuable for future exploration. This is the first study of sulfur isotopes undertaken in the Lycksele-Storuman area. Stable isotope data, here interpreted in the context of the regional and local geology, and the estimated timing of mineralization, in combination with previously published fluid inclusion data (Bark et al. 2007), suggest that the Fäboliden gold deposit was formed from mixing of metamorphic and ${ }^{18} \mathrm{O}$-enriched magmatic fluids during rapid uplift and erosion, after peak metamorphism.

\section{Regional geological setting}

Rifting of the Archaean craton during the early Proterozoic generated a large oceanic basin, the Bothnian Basin, along a continental margin (Gaál and Gorbatschev 1987; Nironen 1997). This basin was filled primarily with $>10 \mathrm{~km}$ thick metasedimentary sequences that commonly host carbonate concretions (Kumpulainen 2009), and subordinate metavolcanic rocks (Lundqvist 1987). Later, these supracrustal rocks, which are indirectly dated at >1.95 Ga (Wasström 1993, 1996; Eliasson and Sträng 1998; Eliasson et al. 2001), were intruded by several generations of granitoids and, to a lesser extent, by gabbros, during the 1.9-1.8 Ga Svecofennian orogeny (Claesson and Lundqvist 1995). This complex orogeny has been subdivided into phases of both extensional and collisional tectonic regimes by Lahtinen et al. $(2003,2005)$. During collisional tectonic stages and subsequent orogenic collapse (Lahtinen et al. 2005), the supracrustal rocks of the LyckseleStoruman area (Fig. 1) were intruded by S-type granites of the Skellefte-Härnö suite, dated at c. 1.82-1.80 Ga and alkali-calcic granites of the Revsund suite with ages between 1.80 and $1.77 \mathrm{Ga}$ (Claesson and Lundqvist 1995; Billström and Weihed 1996; Weihed et al. 2002a).

\section{Fäboliden orogenic gold deposit}

The steeply dipping sheet-like deposit at Fäboliden extends for about $1.3 \mathrm{~km}$ along strike (Fig. 2), is up to $50 \mathrm{~m}$ wide, and has been observed at depths of over $350 \mathrm{~m}$. The mineralized zone is open at depth.

\section{Geology of the Fäboliden area}

The main rock type in the Fäboliden area (Fig. 2) is the late- to post-orogenic, 1.80-1.77 Ga, Revsund granitoid (Claesson and Lundqvist 1995; Billström and Weihed 1996; Weihed et al. 2002a). This medium- to coarse-grained porphyritic, isotropic granitoid surrounds a narrow belt of Bothnian Basin metagreywackes intercalated with mafic metavolcanic rocks. The poorly exposed fine-grained and biotite-rich metagreywackes are strongly foliated. In a few outcrops, the metagreywackes are more coarse-grained $(<1 \mathrm{~cm}$ grain size $)$ and less deformed. In less deformed areas, primary sedimentary textures such as stratification and bedding are observed. The fine-grained and banded metavolcanic rocks dominate the northern parts of the Fäboliden area.

The granitic and supracrustal rocks in the Fäboliden area are crosscut by a set of c. $1.26 \mathrm{Ga}$ dolerites (Söderlund et al. 2006). The dolerites are not mineralized, and clearly post-date the gold mineralization at Fäboliden.

\section{Metamorphic conditions}

The metasedimentary rocks in the northern part of the Bothnian Basin, the Lycksele-Storuman area (Fig. 1), have been metamorphosed to amphibolite facies (Weihed et al. 1992), and locally to granulite facies (Lundström 1998). Regional metamorphic PT conditions of 3-5 kbar and $550-700{ }^{\circ} \mathrm{C}$ were suggested by Lundqvist (1990). Geothermometric data from supracrustal rocks indicate peak metamorphic temperatures of $570-640{ }^{\circ} \mathrm{C}$ (garnetbiotite) for the Fäboliden area (Bark and Weihed 2007, 2012), suggesting amphibolite facies conditions. Peak metamorphism and known ductile deformation events in the northern part of the Bothnian Basin occurred between 1.84 and $1.80 \mathrm{Ga}$ (Weihed et al. 1992; Billström and Weihed 1996; Bergman Weihed 2001; Rutland et al. 2001; Weihed et al. 2002b). Based on aeromagnetic data that show discrete shear zones, denoted as $\mathrm{D}_{3}$-structures, and their field relations with intrusive rocks, Rutland et al. (2001) inferred that the last of the ductile events occurred prior to $1.81 \mathrm{Ga}$. However, in the Fäboliden deposit area, located west of the study area of Rutland et al. (2001), discrete ductile shear zones interpreted as regional $\mathrm{D}_{3^{-}}$ structures host the gold within the supracrustal rocks. These shear zones at Fäboliden are seen to affect the margin of the 1.80-1.77 Ga (Claesson and Lundqvist 1995; Billström and Weihed 1996; Weihed et al. 2002a) Revsund granite in a ductile manner (Bark and Weihed 2003). The ductile fabric, which is sub-parallel to the contact between the metagreywacke and the granite, progresses laterally across the contact where it gradually weakens and disappears a few meters into the granite. These relationships contradict Rutland et al. (2001) and clearly show that the margin of the granite was affected by ductile deformation, requiring the last known ductile event to be c. $1.80 \mathrm{Ga}$. 

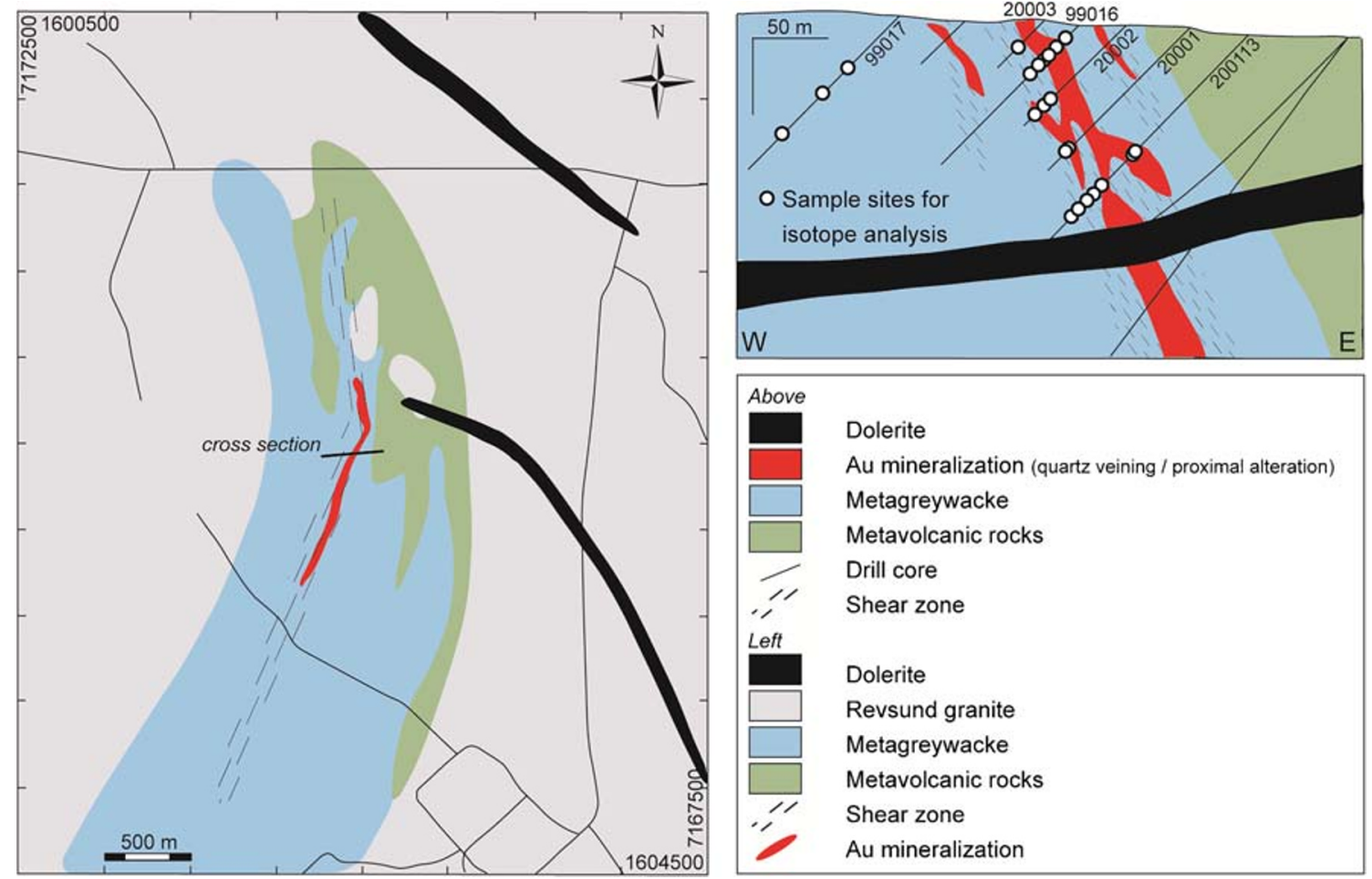

Fig. 2 Bedrock map of the Fäboliden area, with a cross section of the main gold ore zone with sample sites indicated. Coordinates in Swedish National Grid (RT90). Map modified after Björk and Kero (2002)

\section{Timing of mineralization}

Bark and Weihed (2007) discussed the relationships between garnet-biotite and graphite geothermometers from the Fäboliden area, representing peak metamorphic temperatures (garnet-biotite) and temperatures of gold-associated hydrothermal alteration (graphite grains spatially associated with arsenopyrite in the gold-bearing quartz veins). Graphite is a good indicator of temperature conditions, since the process of graphitization of carbonaceous material (CM) in metasedimentary rocks during hydrothermal alteration is considered irreversible and shows no known effects on the crystal structure during retrograde cooling of the rocks (Pasteris and Wopenka 1991; Beyssac et al. 2002). Graphite in the Fäboliden veins is suggested to have originated from the reaction $\mathrm{CO}_{2}+\mathrm{CH}_{4}->2 \mathrm{C}+2 \mathrm{H}_{2} \mathrm{O}$, during mineralization (Bark et al. 2007). Although graphite thermometry studies typically focus on analyses of CM from metasedimentary rocks and not vein-hosted graphite, Beyssac et al. (2002) have shown that graphite thermometry is less sensitive to different $\mathrm{CM}$ precursor types at temperatures between 330 and $650{ }^{\circ} \mathrm{C}$. Thus, since graphite data from Fäboliden suggest a narrow range of peak temperatures $\left(520-560{ }^{\circ} \mathrm{C}\right)$ for the graphitization and associated hydrothermal alteration, considerably lower than peak metamorphic temperatures $\left(570-640{ }^{\circ} \mathrm{C}\right)$ indicated from garnet-biotite geothermometers (Bark et al. 2007) the use of graphite thermometry in veins at Fäboliden is justified. Assuming that the geological environment at Fäboliden did not act as a closed system after the mineralizing event, the graphite temperature range suggests that gold mineralization occurred post-peak metamorphism; otherwise, the graphite geothermometer would have indicated temperatures matching peak metamorphic conditions.

The field observations of the ductile fabric (shearing) that passes from the metagreywacke into the granite, together with the relationship between the different geothermometers, suggests that the gold mineralization at Fäboliden is considered post-peak metamorphic and contemporaneous with the emplacement of the 1.80-1.77 Ga Revsund granite.

\section{Gold mineralization}

The gold at Fäboliden is contained in quartz and sulfide veins, which parallel the main foliation within the shear zone in the supracrustal host rocks (Fig. 2). The metagreywacke sequences are the main host for the veins, which are variably boudinaged. In places, the metavolcanic rocks are also mineralized. Gold has not been observed in the Revsund granite. 
The sulfides are situated in semi-ductile structures, i.e. in thin veins parallel to the foliation planes and in the necks of boudinaged quartz veins indicating that the timing of sulfide crystallization is syn- to late-deformation (Bark and Weihed 2003, 2007).

Sulfides proximal to the mineralization comprise mainly arsenopyrite, löllingite (commonly as inner cores in arsenopyrite; Fig. 3b) and pyrrhotite with accessory chalcopyrite, sphalerite, stibnite, and galena, whereas distal to the mineralization, pyrrhotite is the dominant sulfide and Asbearing minerals are virtually absent. Pyrrhotite occurs throughout the metagreywacke sequence at Fäboliden and is interpreted to have formed prior to the mineralization event. However, in the proximal alteration zone, pyrrhotite commonly occurs as fracture fillings within the arsenopyrite, suggesting that arsenopyrite crystallized prior to pyrrhotite. This paragenetic relationship is also indicated from fluid inclusion analysis where PT conditions are significantly different between fluid inclusions associated with arsenopyrite, at $4 \mathrm{kbar}$, compared with $0.3 \mathrm{kbar}$ for pyrrhotite (Bark et al. 2007). For example, these contradictory textural relationships between arsenopyrite and pyrrhotite might be an effect of re-mobilization of early-stage pyrrhotite during gold mineralization, reflected by late pyrrhotite textures.

Gold is typically very fine-grained (below $10 \mu \mathrm{m}$ ), and occurs mainly as inclusions and as fissure fillings in the arsenopyrite-löllingite (Fig. 3), but also as free grains in the silicate matrix of the host rocks (Bark and Weihed 2003, 2007). Gold typically occurs as elec-

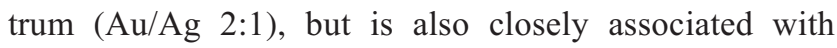
stibnite, as auriferous stibnite.

\section{Hydrothermal alteration}

The supracrustal rocks in the northern parts of the Bothnian Basin constitute metagreywacke sequences with subordinate, mainly mafic, metavolcanic rocks, and are metamorphosed to amphibolite facies (Weihed et al. 1992; Lundström 1998). The mineral assemblage in the metagreywackes is characterized by $\mathrm{Ca}-$ and $\mathrm{Fe}$ Mg-rich amphiboles together with hedenbergite, biotite, quartz, plagioclase, and potassium feldspar. Pyrrhotite is a common constituent together with trace amounts of chalcopyrite, sphalerite, and galena.

The transition from regional metamorphic mineral assemblages to hydrothermal alteration assemblages is gradual. Lower amphibole contents in the distal alteration zone compared with those in regional metamorphic rocks is the only discernible feature that distinguishes these rocks. This style of vague distal alteration
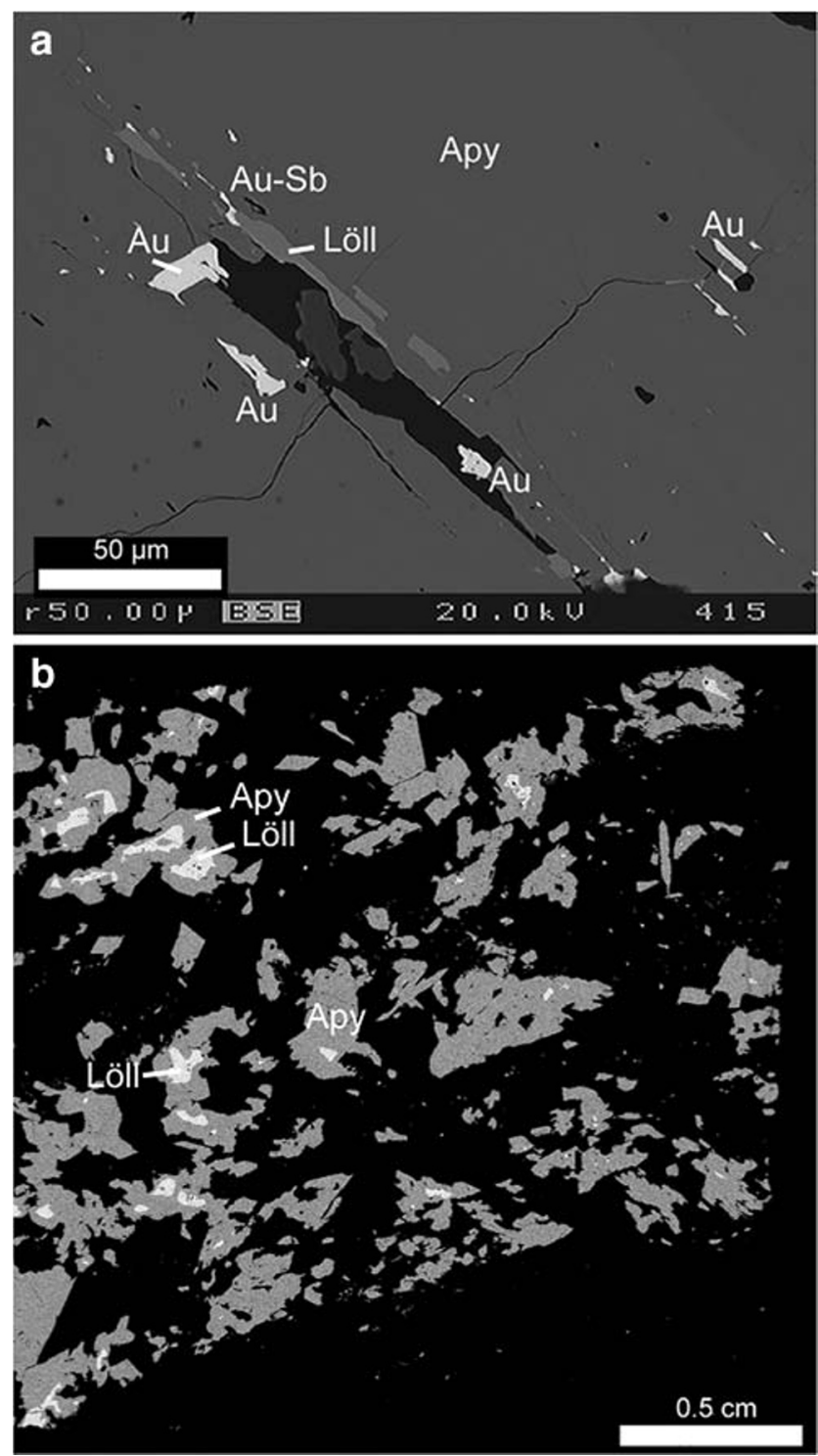

Fig. 3 Electron backscatter images of gold closely associated with arsenopyrite-löllingite. a Gold and probable stibnite in fractures within arsenopyrite-löllingite. b Electron microprobe mapping image (intensity of As) showing arsenopyrite with common löllingite cores. Apy, arsenopyrite; Au, gold; Löll, löllingite; Sb, probable stibnite

is a common feature for hypozonal orogenic gold deposits globally (Eilu et al. 1999).

Proximal to the mineralized zones, the metagreywacke displays an intense compositional banding due to variations in the abundances of biotite, amphibole, and pyroxene. Quartz veins $1-5 \mathrm{~cm}$ thick are common in these proximal alteration zones. Alteration zones enveloping the veins are comprised of diopside, calcic amphibole, biotite, potassium feldspar, plagioclase, minor andalusite, and very fine-grained tourmaline (Bark and Weihed 2007). Compared with regional metamorphic mineral assemblages, proximal alteration zones contain 
more calcium-rich minerals, manifested by a higher Ancontent of plagioclase. Higher An-content plagioclase, together with the presence of diopside and calcic amphiboles, is positively correlated with higher $\mathrm{Au}$ grade. There are also thinner mineralized lenses parallel to higher grade veins, termed satellite veins, that show intense diopside-amphibolebiotite alteration (Fig. 2, see cross section).

\section{Analytical methods}

Quartz and biotite from the quartz vein system were analyzed for oxygen and hydrogen isotopes. Arsenopyrite and pyrrhotite from the vein system were analyzed for sulfur isotopes. In total, six drill cores were sampled at 35 different sites (for distribution of samples, see Fig. 2). Fifty-two arsenopyrite, 17 pyrrhotite, 14 quartz, and 7 biotite grains were analyzed in this study. Samples were crushed and sieved to $75 \mu \mathrm{m}$. Minerals were separated using magnetic separation in two steps, followed by handpicking of targeted minerals under stereographic microscope. Isotopic analysis was subsequently performed at the Scottish Universities Environmental Research Centre (S.U.E.R.C.) in Glasgow, Scotland.

\section{Oxygen isotope analysis}

All separates were analyzed using a laser fluorination procedure, involving total sample reaction with excess $\mathrm{ClF}_{3}$ using a $\mathrm{CO}_{2}$ laser as a heat source (in excess of $1500{ }^{\circ} \mathrm{C}$; following Sharp 1990). All combustion resulted in $100 \%$ release of $\mathrm{O}_{2}$ from the silica lattice. This $\mathrm{O}_{2}$ was then converted to $\mathrm{CO}_{2}$ by reaction with hot graphite, then analyzed online by a $\mathrm{VG}$ SIRA 10 spectrometer. Reproducibility is better than $\pm 0.3 \%$ o $(1 \sigma)$. Results are reported in standard notation $\left(\delta^{18} \mathrm{O}\right)$ as per mil (\%o) deviations from the Standard Mean Ocean Water (VSMOW) standard, in Table 1.

\section{Hydrogen isotope analysis}

Pure biotite samples were heated to $150{ }^{\circ} \mathrm{C}$ overnight under high vacuum to release labile volatiles after loading into thoroughly outgassed Pt crucibles. Samples were then gradually heated by radiofrequency induction in an evacuated quartz tube, to temperatures in excess of $1200^{\circ} \mathrm{C}$. The released water was then reduced to $\mathrm{H}_{2}$ in a chromium furnace at $800{ }^{\circ} \mathrm{C}$ (Donnelly et al. 2001), with the evolved gas measured quantitatively in a $\mathrm{Hg}$ manometer, before collecting using a Toepler pump. The gas was subsequently analyzed on a VG 602D mass spectrometer with a manual $\mathrm{Hg}$, high gas-compression inlet system. Replicate analyses of water standards
Table 1 Oxygen and hydrogen isotope data from Fäboliden

\begin{tabular}{llcc}
\hline Sample & Mineral & $\delta^{18}$ O mineral & $\delta$ D mineral \\
\hline FA20001-104.95ma & Biotite & & -95 \\
FA20001-104.95mb & Biotite & 7.3 & -95 \\
FA20002-075.20m & Biotite & & -67 \\
FA200113-144.05m & Biotite & & -80 \\
FA200113-151.33ma & Biotite & & -120 \\
FA200113-151.33mb & Biotite & 7.7 & -71 \\
FA200113-169.25m & Biotite & & -91 \\
FA99016-033.05ma & Biotite & & \\
FA99016-033.05mb & Biotite & 8.0 & \\
FA99016-050.10m & Biotite & & \\
FA20001-104.95m & Quartz & 11.4 & \\
FA20002-073.70m & Quartz & 11.3 & \\
FA20002-075.20m & Quartz & 11.6 & \\
FA200113-144.05m & Quartz & 12.2 & \\
FA200113-148.00m & Quartz & 12.0 & \\
FA200113-151.33m & Quartz & 11.4 & \\
FA200113-160.34m & Quartz & 11.2 & \\
FA200113-166.71m & Quartz & 12.0 & \\
FA200113-169.25m & Quartz & 12.0 & \\
FA99016-025.40m & Quartz & 10.6 & \\
FA99016-033.05m & Quartz & 13.1 & \\
FA99016-036.50m & Quartz & 11.6 & \\
FA99016-041.65m & Quartz & 12.2 & \\
FA99016-050.10m & Quartz & 11.9 & \\
\hline
\end{tabular}

All values in per mil

(international stds V-SMOW and GISP, and internal standard Lt Std) gave a reproducibility of $\pm 2 \%$. Replicate analyses of international mineral standard NBS-30 (biotite) of $\delta \mathrm{D}=-$ $65 \%$ (V-SMOW) also gave reproducibility around $\pm 2 \%$. Analytical results are summarized, as $\delta \mathrm{D}$ notation as per mil (\%o) variations from the international V-SMOW standard, in Table 1.

\section{Sulfur isotope analysis}

Sulfide separates (arsenopyrite and pyrrhotite) were analyzed by conventional techniques (Robinson and Kusakabe 1975) in which $\mathrm{SO}_{2}$ gas was liberated by combusting the sulfides under vacuum with excess $\mathrm{Cu}_{2} \mathrm{O}$ at $1075^{\circ} \mathrm{C}$. In addition to the conventional analysis, a number of in situ laser combustion analyses were carried out on polished blocks of the respective sample, following the technique described in Wagner et al. (2004). This allowed a spatial resolution of sulfur isotopes to be undertaken (McConville et al. 2000). 
Liberated gases from both techniques were analyzed on a VG Isotech SIRA II mass spectrometer. Calculation of $\delta^{34} \mathrm{~S}$ values from raw machine $\delta^{66} \mathrm{SO}_{2}$ data was carried out by calibration with international standards NBS-123 (+17.1\%o) and IAEA-S-3 $(-31.5 \%$ ) , as well as SUERC's internal lab standard CP-1 $(-4.6 \%$ o). Reproducibility was better than \pm $0.2 \%$ o $(1 \sigma)$. Data are reported in $\delta^{34} \mathrm{~S}$ notation as per mil (\%o) variations from the Vienna Cañon Diablo Troilite (V-CDT) standard. The analytical results, for conventional and laser-combusted sulfur analysis, are summarized in Tables 2 and 3. The majority (about $80 \%$ ) of sulfur

Table 2 Sulfur isotope data for arsenopyrite and pyrrhotite, from the Fäboliden deposit using conventional analysis

\begin{tabular}{|c|c|c|}
\hline Sample & Mineral & $\delta^{34} \mathrm{~S}_{\mathrm{V}-\mathrm{CDT}}(\%)$ \\
\hline FA20002-073.70ma & Arsenopyrite & 0.2 \\
\hline FA20002-073.70mb & Arsenopyrite & 0.4 \\
\hline FA20002-075.20m & Arsenopyrite & 0.6 \\
\hline FA20003-037.75m & Arsenopyrite & 0.0 \\
\hline FA200113-122.87m & Arsenopyrite & -0.1 \\
\hline FA200113-123.00m & Arsenopyrite & 0.0 \\
\hline FA200113-148.00ma & Arsenopyrite & 1.3 \\
\hline FA200113-148.00mb & Arsenopyrite & 1.5 \\
\hline FA200113-149.45m & Arsenopyrite & 1.0 \\
\hline FA200113-149.82m & Arsenopyrite & 1.8 \\
\hline FA200113-155.70ma & Arsenopyrite & -0.4 \\
\hline FA200113-155.70mb & Arsenopyrite & 0.9 \\
\hline FA200113-157.32m & Arsenopyrite & 0.2 \\
\hline FA200113-160.17m & Arsenopyrite & -0.4 \\
\hline FA200113-160.34m & Arsenopyrite & -0.5 \\
\hline FA99016-025.40ma & Arsenopyrite & 0.9 \\
\hline FA99016-036.50m & Arsenopyrite & 2.6 \\
\hline FA99016-041.65m & Arsenopyrite & 1.6 \\
\hline FA99016-042.00m & Arsenopyrite & 1.6 \\
\hline FA99016-043.80m & Arsenopyrite & -0.9 \\
\hline FA99016-048.52m & Arsenopyrite & 1.7 \\
\hline FA20002-082.90m & Pyrrhotite & 0.4 \\
\hline FA200113-144.05m & Pyrrhotite & 0.5 \\
\hline FA200113-151.33m & Pyrrhotite & 0.2 \\
\hline FA200113-160.34m & Pyrrhotite & -0.8 \\
\hline FA200113-166.71m & Pyrrhotite & 0.0 \\
\hline FA200113-169.25m & Pyrrhotite & -1.5 \\
\hline FA99016-050.10m & Pyrrhotite & 0.1 \\
\hline FA99017-039.10m & Pyrrhotite* & 0.8 \\
\hline FA99017-076.65m & Pyrrhotite* & -2.6 \\
\hline FA99017-116.55m & Pyrrhotite* & -3.3 \\
\hline
\end{tabular}

V-CDT Vienna Cañon Diablo Troilite

*Least altered samples
Table 3 Sulfur isotope data for arsenopyrite and pyrrhotite, from the Fäboliden deposit using laser combustion analysis

\begin{tabular}{|c|c|c|c|}
\hline Sample & Mineral & Comments & $\delta^{34} \mathrm{~S}_{\mathrm{V}-\mathrm{CDT}}(\%){ }^{1}$ \\
\hline FA20001-106.95ma & arsenopyrite & core & 2.7 \\
\hline FA20001-106.95mb & arsenopyrite & rim & 2.6 \\
\hline FA20002-073.70ma & arsenopyrite & rim & 2.5 \\
\hline FA20002-073.70mb & arsenopyrite & core & 1.4 \\
\hline FA20002-073.70mc & arsenopyrite & rim & 1.9 \\
\hline FA20002-075.20ma & arsenopyrite & core & 1.7 \\
\hline FA20002-075.20mb & arsenopyrite & core & 1.9 \\
\hline FA20003-037.75m & arsenopyrite & rim & 1.7 \\
\hline FA200113-122.87ma & arsenopyrite & core & 0.6 \\
\hline FA200113-122.87mb & arsenopyrite & core & -0.1 \\
\hline FA200113-132.80m & arsenopyrite & core & -0.2 \\
\hline FA200113-146.29m & arsenopyrite & core & 1.2 \\
\hline FA200113-146.43m & arsenopyrite & rim & 1.7 \\
\hline FA200113-146.57m & arsenopyrite & rim & 3.6 \\
\hline FA200113-148.00ma & arsenopyrite & rim & 2.3 \\
\hline FA200113-148.00mb & arsenopyrite & core & 2.4 \\
\hline FA200113-149.45m & arsenopyrite & core & 0.3 \\
\hline FA200113-150.78m & arsenopyrite & core & 1.2 \\
\hline FA200113-151.63m & arsenopyrite & core & 0.9 \\
\hline FA200113-155.70m & arsenopyrite & core & 1.6 \\
\hline FA200113-157.32m & arsenopyrite & core & 1.2 \\
\hline FA200113-160.17m & arsenopyrite & core & 1.0 \\
\hline FA200113-160.34ma & arsenopyrite & core & -0.8 \\
\hline FA200113-160.34mb & arsenopyrite & rim & 0.4 \\
\hline FA99016-036.50m & arsenopyrite & core & 2.3 \\
\hline FA99016-042.00ma & arsenopyrite & rim & 2.7 \\
\hline FA99016-042.00mb & arsenopyrite & core & 1.6 \\
\hline FA99016-043.80m & arsenopyrite & core & 0.2 \\
\hline FA99016-047.92m & arsenopyrite & rim & 0.6 \\
\hline FA99016-048.35m & arsenopyrite & core & 1.8 \\
\hline FA99016-048.52m & arsenopyrite & $\mathrm{rim} / \mathrm{core}$ & 1.6 \\
\hline FA20002-075.20ma & pyrrhotite & core & 0.8 \\
\hline FA20002-075.20mb & pyrrhotite & core & 1.0 \\
\hline FA20003-037.75m & pyrrhotite & rim & 0.0 \\
\hline FA200113-150.78m & pyrrhotite & core & 0.8 \\
\hline FA200113-151.63m & pyrrhotite & rim & 0.5 \\
\hline FA99016-042.00m & pyrrhotite & rim & 1.9 \\
\hline FA99016-048.35m & pyrrhotite & core & 1.5 \\
\hline
\end{tabular}

${ }^{1}$ All values were corrected from raw $\delta^{34} \mathrm{~S}$ values, using the laser fractionation factor determined by Wagner et al. (2004) whereby; $\delta^{34} \mathrm{~S}_{\text {true }}=\delta^{34} \mathrm{~S}_{\text {measured }}+0.4$, which is the same as that calculated for pyrrhotite by Maynard et al. (1997). Shaded rows indicate core and rim analysis in one and the same grain 
isotope analyses were made on arsenopyrite since the arsenopyrite is considered to be associated with the precipitation of gold at Fäboliden (Bark et al. 2007).

\section{Results}

\section{Oxygen and hydrogen isotope data}

Results of oxygen and hydrogen isotope analysis are presented in Table 1. The oxygen isotope compositions of quartz from the auriferous veins at Fäboliden are homogeneous and range between +10.6 and $+13.1 \%$. The mean value for the quartz data is $+11.8 \pm 0.6 \%$ o $(1 \sigma, n=14)$.

Oxygen isotope compositions of biotite samples show a narrow $\delta^{18} \mathrm{O}$ range of +7.3 to $+8.0 \%$. Hydrogen isotope $(\delta \mathrm{D})$ compositions range from -120 to $-67 \%$ (Table 1), with the majority of compositions between -95 and $-67 \%$. The mean $\delta \mathrm{D}$ value is $-88 \pm 18 \%$ o $(1 \sigma, n=7)$.

Assuming there was equilibrium between fluids and minerals, the isotopic compositions for $\delta \mathrm{D}$ and $\delta^{18} \mathrm{O}$ of fluids (Fig. 4) were calculated based on temperatures from graphite geothermometry $\left(520-560{ }^{\circ} \mathrm{C}\right)$ from the proximal alteration zone at Fäboliden (Bark et al. 2007). The calculated $\delta^{18} \mathrm{O}$ fluid values from quartz range between +8.5 and $+11.3 \%$ and from biotite between +9.8 and $+10.5 \%$ o (Bottinga and Javoy 1973; Matsuhisa et al. 1979). Mean calculated fluid $\delta^{18} \mathrm{O}$ for quartz is $+9.6 \pm 0.6 \%$ (at $520{ }^{\circ} \mathrm{C}$ ) and $+9.9 \pm$ $0.6 \%$ (at $560{ }^{\circ} \mathrm{C}$ ), and for biotite $+10.1 \%$ o $\left(520-560{ }^{\circ} \mathrm{C}\right.$ ).
Therefore, statistically, these minerals are in isotopic equilibrium with the same fluid at the noted temperatures. The calculated $\delta \mathrm{D}$ compositions of fluids are between -85 and $-32 \%$, with most data above $-60 \%$ o (Suzuoki and Epstein 1976). The mean value for $\delta \mathrm{D}$ fluid is -55 and $-51 \%$ at $520^{\circ} \mathrm{C}$ and $560^{\circ} \mathrm{C}$, respectively.

\section{Sulfur isotope data}

Results of sulfur isotope analysis show a marked isotopic homogeneity (Tables 2 and 3 and Fig. 5). Conventional analysis yielded $\delta^{34} \mathrm{~S}$ values for arsenopyrite from -0.9 to $+2.6 \%$ o (Fig. 5a), with a mean value of $0.7 \pm 0.9 \% o(1 \sigma, n=21)$. Compositions in pyrrhotite range from -1.5 to $+0.5 \%$, with a mean value of $-0.2 \pm 0.7 \%$ o $(1 \sigma, n=7)$.

A higher spatial resolution compared with conventional methods was gained by analyzing individual arsenopyrite and pyrrhotite grains in situ using laser combustion techniques. Most analyses were of arsenopyrite because it is temporally associated with gold at Fäboliden (Bark et al. 2007), but some pyrrhotite was also analyzed. In total, 23 arsenopyrite and 6 pyrrhotite samples were analyzed. In each sample, one mineral grain was analyzed, but the core and rims of 7 arsenopyrite and 1 pyrrhotite grains were also analyzed. The rims and cores of the minerals were analyzed to test within-grain sulfur isotope compositional variations (Table 2). The arsenopyrite cores yielded $\delta^{34} \mathrm{~S}$ values from -0.8 to $+2.3 \%$ o $(n=19)$, whereas the rims ranged between 0 and $+3.6 \%$ o $(n=11$; Fig. $5 \mathrm{~b})$. The mean and $1 \sigma$ standard
Fig. 4 Diagram showing the range in calculated fluid oxygen (quartz and biotite) and hydrogen (biotite) isotope compositions. The bold red bar in the center of the symbol indicates mean oxygen and hydrogen values, in the temperature range 520 and $560{ }^{\circ} \mathrm{C}$. Fractionations for $\delta \mathrm{D}$ after Suzuoki and Epstein (1976), and for $\delta^{18} \mathrm{O}$ quartz-fluid after Matsuhisa et al. (1979). Metamorphic and magmatic fields after Taylor (1974). Orogenic gold field from Ridley and Diamond (2000)

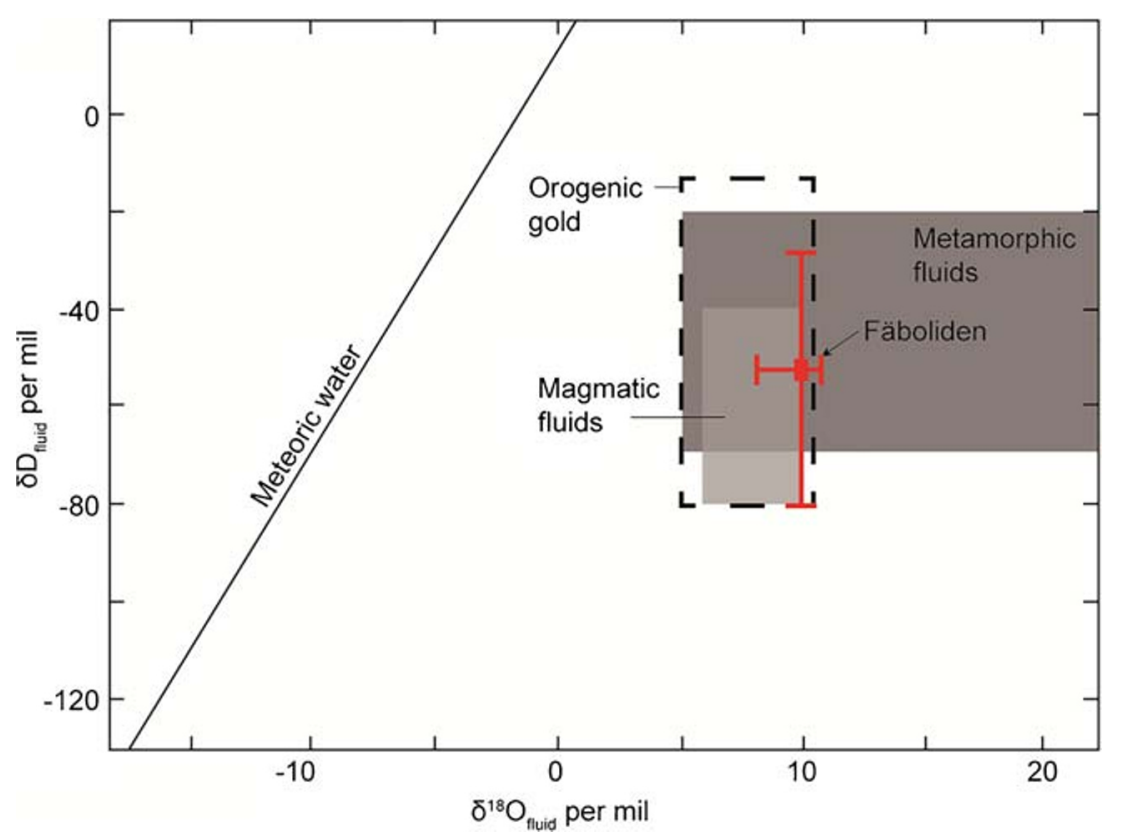



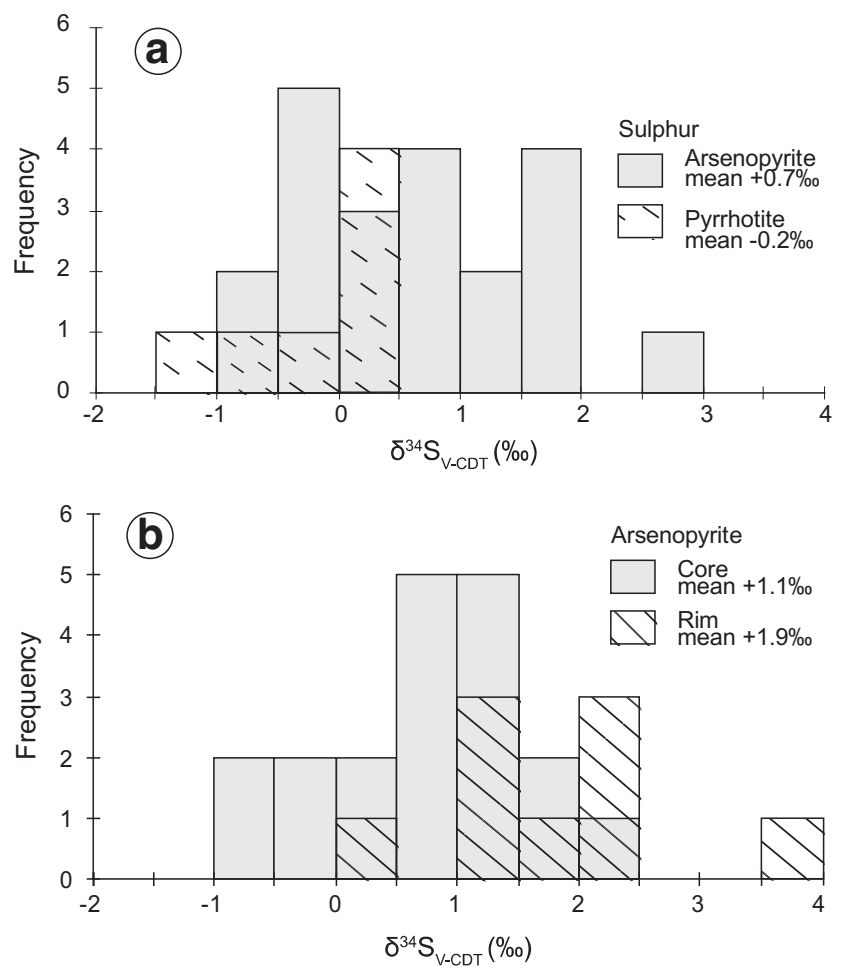

Fig. 5 Frequency diagrams showing $\delta^{34} \mathrm{~S}$ values for arsenopyrite and pyrrhotite. a Conventional analysis. b Laser combustion analysis

deviation of these data are $1.1 \pm 0.9 \%$ and $1.9 \pm 1.0 \%$ for core and rim, respectively. Thus, there is no statistically significant isotopic variation between rim and core in the arsenopyrite data. A similar lack of variation is suggested by analysis of pyrrhotite, yielding a $\delta^{34} \mathrm{~S}$ range in cores of +0.8 to $+1.5 \%$ o $(n=4)$, and analysis of the rims ranging between 0 and + $1.9 \%$ o $(n=3)$. The marked isotopic homogeneity of the dataset is evident in the combined vein sulfide data, which gives a mean of $1.1 \pm 1.0 \%$ for arsenopyrite, and $0.4 \pm 0.9 \%$ for pyrrhotite.

In an attempt to characterize background values of $\delta^{34} \mathrm{~S}$, three weakly altered pyrrhotite samples from about $100 \mathrm{~m}$ outside the proximal alteration zone yielded a $\delta^{34} \mathrm{~S}$ range of -3.3 to $+0.8 \%$. These results overlap the $\delta^{34} \mathrm{~S}$ values from the proximal alteration zone but may indicate a slight shift towards more negative values for pyrrhotite in regional metagreywacke. However, further analysis is required to define a more representative sulfur isotope range for the unaltered metagreywackes in the Fäboliden area.

\section{Discussion}

Metamorphic fluids are widely accepted to be important in the formation of orogenic gold deposits. For example, metamorphic fluids leached metals from the country rocks and were enriched in gold deposits in the Otago Schist Belt, New Zealand, indicating metal transport by metamorphic fluids (Pitcairn et al. 2006). Metamorphic fluids have also been implicated in forming many other gold deposits (Kerrich et al. 2000; Goldfarb et al. 2005; Pitcairn et al. 2006, 2010; Large et al. 2011; Phillips and Powell 2010; Tomkins 2010, 2013; Gaboury 2013; Groves and Santosh 2016; Goldfarb et al. 2017), but orogenic gold deposits have also been suggested to have formed from magmatichydrothermal fluids (Burrows et al. 1986; Pattrick et al. 1988; Burrows and Spooner 1989; de Ronde et al. 2000; Xue et al. 2013), from deep-convection of meteoric water (Nesbitt et al. 1989; Hagemann et al. 1994; Jenkin et al. 1994), from mantle-derived $\mathrm{CO}_{2}$-rich fluids (Cameron 1988, 1989; Colvine 1989), or from fluids expelled during subduction of oceanic crust (Kerrich and Wyman 1990; Goldfarb et al. 1991a; Jia et al. 2003). Mixing of different fluids has also been suggested to be important in causing precipitation of gold in orogenic deposits (Anderson et al. 1992; Bateman and Hagemann 2004; Hill et al. 2013; Molnar et al. 2016; Yardley and Cleverley 2015; Shen et al. 2016; Spence-Jones et al. 2018), whereas some authors dismiss fluid mixing as a significant process in the formation of orogenic gold systems (Goldfarb and Groves 2015). The ultimate fluid source for orogenic gold deposits remains controversial and the fluid may have multiple origins (Goldfarb and Groves 2015; Yardley and Cleverley 2015; Groves and Santosh 2016; Groves et al. 2019).

\section{Origin of fluid}

The calculated fluid oxygen and hydrogen isotope compositions of quartz in the Fäboliden deposit plot in the overlapping fields of metamorphic and magmatic fluids (Fig. 4), suggesting that the hydrothermal fluid at Fäboliden originated from a deep-seated metamorphic and/or magmatic source. The range in oxygen and hydrogen compositions is similar to many other orogenic gold deposits (i.e. McCuaig and Kerrich 1998; Hagemann and Cassidy 2000; Ridley and Diamond 2000; Groves et al. 2003).

Oxygen isotopes from the Fäboliden deposit range from + 10.6 to $+13.1 \%$ o $\left(\delta^{18} \mathrm{O}_{\text {quartz }}\right)$. Oxygen isotope compositions greater than $+8 \%$ are interpreted as being the result of surface or near-surface processes during sedimentation, diagenesis, or low-temperature hydrothermal alteration (Taylor 1980), suggesting that the fluid cannot be solely magmatic (McCuaig and Kerrich 1998). Also, if the source rocks contain ${ }^{18} \mathrm{O}$ enriched metasedimentary rocks, a metamorphic fluid with $\delta^{18} \mathrm{O}$ values greater than $+8 \%$ is possible (Böhlke and Kistler 1986; McCuaig and Kerrich 1998). The $\delta^{18} \mathrm{O}_{\text {fluid }}$ 
values from the Fäboliden gold-bearing metasedimentary host rocks may thus suggest a purely metamorphic fluid source, or a mixed fluid source.

In the Lycksele-Storuman area (Fig. 1), few stable isotope studies have been undertaken. Wilson et al. (1985) presented oxygen isotope data $\left(n=5, \delta^{18} \mathrm{O}_{\mathrm{SMOW}}\right.$ ranging from +9.2 to $+11.8 \%$ ) from two different granitic suites in the northern part of the Bothnian Basin, the Revsund type and the less common Skellefte-Härnö type, and concluded that there is assimilation of pelitic components in both granites but the Skellefte-Härnö type typically has the highest degree of incorporated metasedimentary material. Based on geothermometry and field relations, the mineralizing event at Fäboliden is estimated to be broadly coeval with emplacement of the spatially proximal 1.80-1.77 Ga Revsund granite (Claesson and Lundqvist 1995; Billström and Weihed 1996; Weihed et al. 2002a) (Bark and Weihed 2007). The Skellefte-Härnö type granite is not known to occur in the Fäboliden area. Orogenic gold mineralization at about $1.8 \mathrm{Ga}$ is a global phenomenon (Goldfarb et al. 2001) and an alignment of orogenic gold deposits of assumed similar age occurs in the Fennoscandian Shield both in Sweden and Finland (Saalmann et al. 2009; Bark and Weihed 2012). This suggests that widespread gold-bearing fluids percolated through the Fennoscandian crust at this time. Owing to the fact that the oxygen isotope values of the Revsund granite are interpreted to be the result of assimilation of metamorphosed sedimentary country rocks (Wilson et al. 1985), a Revsund-related magmatic fluid would likely resemble the isotopic oxygen signature of the metamorphosed sedimentary host rocks. It is common that magmatic fluids are present in hydrothermal systems, but the magmatic isotope signature may be strongly overprinted or erased during subsequent events, obscuring the original compositions (Rye 1993; Hedenquist and Lowenstern 1994; Hoefs 2009; Pili et al. 2011; Yardley and Cleverley 2015; Lüders et al. 2015; Goldfarb et al. 2017).

Therefore, a metamorphic origin of the gold-mineralizing fluid at Fäboliden seems plausible but a magmatic component to the fluid cannot be ruled out.

\section{Origin of sulfur}

Gold is likely transported as bisulfide complexes in metamorphic fluids that produced orogenic gold deposits (Groves et al. 2003; Goldfarb et al. 2005), especially at high pressure and temperature conditions $\left(550-725^{\circ} \mathrm{C}\right.$ and $1-4$ kbar; Loucks and Mavrogenes 1999). Therefore, the source of sulfur is an important factor in developing a genetic model.

The remarkable homogeneity of sulfur isotope compositions for all vein sulfide samples, showing a mean value of $+1.1 \pm 1.0 \%$ o for arsenopyrite, and $+0.4 \pm 0.9 \%$ for pyrrhotite, suggests that the sulfur likely originated from one uniform source reservoir. A narrow range of sulfur isotope values that cluster around $0 \%$ o was previously considered consistent with a magmatic source for the sulfur (Ohmoto and Rye 1979). However, the local host rock can have a significant effect on the isotope signature (Ohmoto and Goldhaber 1997).

The dominant host rock at Fäboliden is a thick sequence (> $10 \mathrm{~km}$ ) of schistose metagreywacke, with carbonate-rich parts, intercalated with metavolcanic units (Bark and Weihed 2007). The role of black shales, diagenetic pyrite, and orogenic gold formation in sedimentary host rocks has been illustrated in a number of studies (Large et al. 2007, 2009, 2011; Thomas et al. 2011; Gaboury 2013). The model assumes that diagenetic pyrite is later transformed into pyrrhotite during metamorphism and deformation, releasing the gold from the pyrite crystal structure and concentrating the gold during orogenic processes, forming gold deposits. Carbonaceous shales are a suitable source rock for elements that are commonly enriched in orogenic gold deposits, such as $\mathrm{S}, \mathrm{Au}, \mathrm{As}$, and Sb (Large et al. 2011; Pitcairn 2011; Steadman et al. 2014; Lisitsin and Pitcairn 2015).

Sedimentary rocks commonly show a wide range $(+50$ to $-40 \%$ o) in initial sulfur isotopic composition (Fig. 6) (Ohmoto and Rye 1979; Ohmoto 1986; Ohmoto and Goldhaber 1997; Seal 2006; Hoefs 2009). A wide range of compositions suggests either a mixture of sulfur from different sources under reduced conditions, or precipitation of sulfur from a single source under more oxidizing conditions (Ohmoto and Rye 1979). However, subsequent geological processes can modify the initial isotopic signatures. Metamorphism is commonly assumed to homogenize isotope compositions of sulfides through recrystallization, alteration of pyrite to pyrrhotite and sulfur, and diffusion at increased temperatures (Cook and Hoefs 1997). However, isotopic homogenization is commonly restricted to specific parts of the deposit and is controlled by local conditions such as focused fluid flow and tectonic framework (Cook and Hoefs 1997). Chang et al. (2008) showed that variable sulfur isotope compositions in rocks hosting the Sukhoi Log orogenic gold deposit in Russia were homogenized during metamorphism and peak deformation.

Compilations of sulfur isotope data from a large number of deposits show a common range of $\delta^{34} \mathrm{~S}$ compositions from -3 to $+9 \%$ for orogenic lode gold deposits globally (Steed and Morris 1997; McCuaig and Kerrich 1998; Ramsay et al. 1998; Ridley and Diamond 2000; Hodkiewicz et al. 2009). Fäboliden sulfur isotope data clearly fall within this range, with $\delta^{34} \mathrm{~S}$ between -1.5 and $+3.6 \%$ (Fig. 5), a narrow range that is similar to other hypozonal orogenic gold deposits, such as the giant Champion deposit in the Kolar Schist Belt, India (Hagemann and Cassidy 2000) and the Wiluna, Morning Star, 
Fig. 6 Sulfur isotope ranges of some common reservoirs. Data compiled from Steed and Morris 1997, McCuaig and Kerrich 1998, Ramsay et al. 1998, Ridley and Diamond 2000, Hodkiewicz et al. 2009, and Hoefs 2009

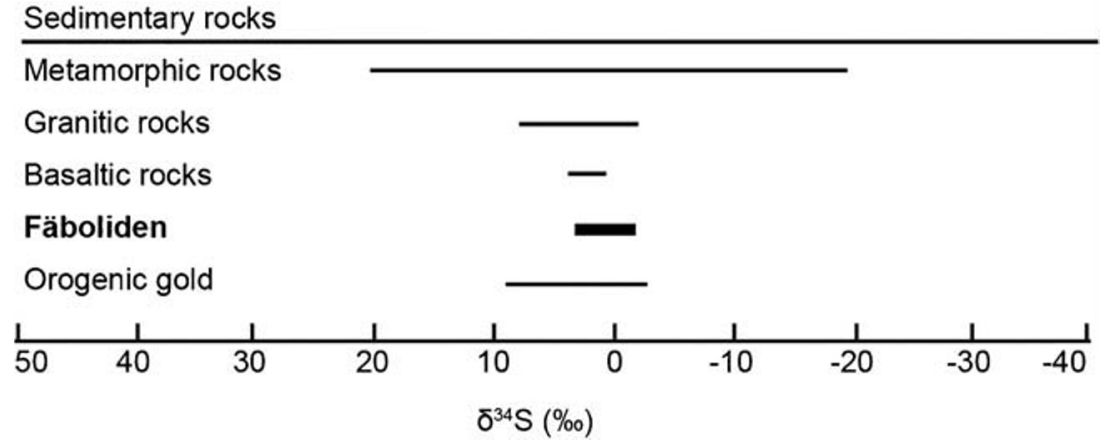

Princess Royal, and Mt. Charlotte deposits in Australia (McCuaig and Kerrich 1998). This range of $\delta^{34} \mathrm{~S}$ in the gold-associated sulfide minerals has been interpreted to originate from common sulfur reservoirs such as mantle-derived magmatic rocks, average crustal sulfur, or metamorphosed sedimentary sulfur (Ridley and Diamond 2000; Chang et al. 2008).

A narrow range of sulfur isotope data clustering around $0 \%$ o may suggest a single uniform source for the sulfur (and by inference gold). Based on fluid inclusion data, Bark et al. (2007) showed that an extremely $\mathrm{CO}_{2}$-rich fluid (75$95 \mathrm{~mol} \%$ ) was involved in the formation of the Fäboliden deposit. Large amounts of $\mathrm{CO}_{2}$ are generated during metamorphism (Goldfarb et al. 2017), and carbonate-rich sedimentary rocks, such as the metagreywacke sequence at Fäboliden would result in $\mathrm{CO}_{2}$-rich ore-related fluids. This would indicate that the fluid originated from sedimentary rocks beneath the site of ore formation, as is suggested for other hypozonal orogenic gold deposits elsewhere (Kolb et al. 2015). Gaboury (2019) concludes that the fluid, ligand, and metal (gold) involved in orogenic gold mineral systems are all sourced from the same carbonaceous and pyrite-rich sedimentary rock, at conditions transitional between greenschist and amphibolite facies. The Fäboliden data are consistent with this model.

Overall, sulfur, oxygen, and hydrogen isotopic data interpreted in the context of the regional and local geology suggests that the mineralizing fluid at Fäboliden originated from metamorphic devolatilization of deep-seated sedimentary rocks, but there is a possibility that a magmatic fluid triggered precipitation of metals through mixing with the goldbearing metamorphic fluid.

\section{Proposed genetic model}

Models for orogenic gold systems suggest that the fluid is generated during prograde metamorphism at the greenschistamphibolite facies transition. Fluids and sulfur are released from the metamorphosed rocks during the breakdown of hydrous silicates and pyrite (Pitcairn et al. 2006; Tomkins 2010; Finch and Tomkins 2017) and, if the elemental composition of the source rock is favorable (e.g., carbonaceous sedimentary rocks; Vilor 1983; Large et al. 2007, 2009, 2011; Gaboury 2013, 2019), the fluid has the potential of forming orogenic gold deposits, assuming the fluid is focused through a structural framework in the crust with subsequent precipitation of gold over a geologically short time period. The amount of time required to generate an orogenic gold deposit obviously varies with size and gold concentration of the deposit, but the actual duration of the mineralizing event is suggested to be geologically short ( $<1$ m.y.; Goldfarb et al. $1991 b ; 10,000$ to 100,000 years; Weatherley and Henley 2013; Cox 2016), compared with the overall process of regional metamorphism (Yardley and Cleverley 2015). Exceptions are suggested for giant deposits, which may take several tens of millions of years to form (e.g., Golden Mile; Bateman and Hagemann 2004).

The generation of an ore fluid during prograde metamorphism as described above seems like a valid scenario for deposits in greenschist facies, and possibly also at lower amphibolite facies, but the model has difficulty explaining orogenic gold formation in metamorphic terranes at higher PT conditions (Kolb et al. 2015; Groves et al. 2019), or in deposits that clearly post-date peak metamorphism. Based on geothermometric data, mineralization at Fäboliden took place post-peak metamorphism, during retrograde conditions (Bark and Weihed 2007), requiring an alternative model for fluid generation.

The average gold concentration in the upper crust is typically between 0.5 and 5 ppb (Wedepohl 1995; Laznicka 1999; Rudnick and Gao 2003; Pitcairn 2011), and thus, scavenging of gold by metamorphic fluids requires a large volume of crust to generate a hydrothermal gold deposit. Yardley and Cleverley (2015) argued that fluid production during regional metamorphism is a slow process because heat transfers through insulating materials, and there are two possible ways of generating a metamorphic fluid post-peak metamorphism: 
(1) the introduction of post-orogenic magmas that supply heat, generating a metamorphic fluid from dehydration of the metamorphosed rocks, or (2) fast dehydration of the crust during post-orogenic decompression due to rapid uplift and erosion. Metamorphic fluids and associated gold would, in the latter case, be generated as consequences of crustal decompression during uplift that is commonly associated with a shift in the far-field stress regime due to a transition from compressional to transpressional settings (Groves et al. 1987; Goldfarb et al. 1991a; Elmer et al. 2006; Craw et al. 2010; Vry et al. 2010; Yardley and Cleverley 2015; White et al. 2015).

At Fäboliden, a significant decrease in pressure, from 4 to $0.3 \mathrm{kbar}$, during late stages in the fluid evolution at Fäboliden is suggested by Bark et al. (2007). This pressure drop may indicate rapid uplift during rotation of the regional stress regime (Weihed et al. 2005; Bark and Weihed 2012) and subsequent erosion during post-orogenic tectonic settings.

However, coeval to the mineralization at Fäboliden, large volumes of magmatic rocks were emplaced proximal to the site of gold deposition (Bark and Weihed 2007), supplying heat and possibly fluids. Our isotopic data suggest that an input of a magmatic source enriched in ${ }^{18} \mathrm{O}$ from assimilation of sedimentary rocks during emplacement cannot be ruled out. However, the sulfur isotope data coupled with fluid inclusion data (Bark et al. 2007) suggests significant input of metamorphic fluid. Bark et al. (2007) suggested that gold formation at Fäboliden was the result of possible mixing of two fluids $\left(a \mathrm{CO}_{2} \pm \mathrm{CH}_{4}\right.$ fluid and $\mathrm{H}_{2} \mathrm{~S} \pm$ $\mathrm{CH}_{4}$ fluid). Phase separation is a widespread mechanism for precipitating gold from the hydrothermal fluid in orogenic gold systems (Ridley and Diamond 2000; Heinrich 2007), and the mechanism is likely triggered by fluctuations in lithostatic pressure during progressive deformation (e.g., the fault-valve model; Sibson et al. 1988; Cox et al. 1995). At Fäboliden, no evidence for phase separation (such as boiling) has been detected (Bark et al. 2007). This may be due to the limited data set in the fluid inclusion study ( $n=$ 14). However, the $\mathrm{CH}_{4}$-component in the fluid is a strong reductant and would likely cause precipitation of gold from the fluid in case of fluid mixing (Heinrich 2007).

\section{Conclusions}

The Fäboliden orogenic gold deposit was formed from a metamorphic fluid, that provided the sulfur (and gold), generated during retrograde metamorphism of deep-crustal sedimentary rocks during decompressional uplift. The metamorphic fluid is suggested to have mixed with an ${ }^{18} \mathrm{O}$-enriched magmatic fluid, causing precipitation of $\mathrm{Au}$ and the formation of the Fäboliden hypozonal orogenic gold deposit. Since the
Fäboliden deposit is hosted by amphibolite facies rocks, and formed post-peak metamorphism, this contribution adds important data to the understanding of the formation of orogenic gold deposits in high-metamorphic terrains.

The authors obviously recognize that using only stable isotope data in constraining an ore model is limiting; however, all interpretations made from isotope data in this paper are corroborated with already published data on geochemistry, mineralogy, petrography, and fluid inclusion data from the Fäboliden deposit.

Acknowledgments Karen Kelley and Bernd Lehmann are thanked for constructive editorial work, and two anonymous reviewers significantly improved the manuscript. The authors would also like to thank the lab staff at S.U.E.R.C. for excellent support.

Funding information Open access funding provided by Lulea University of Technology. This study is funded by Georange, being part of the Georange research project 89126: Genesis and tectonic setting of Aulode in the new Lycksele-Storuman ore province. S.U.E.R.C. is funded by NERC and the consortium of Scottish Universities. AJB is funded by the NERC support of the Isotope Community Support Facility at S.U.E.R.C.

Open Access This article is licensed under a Creative Commons Attribution 4.0 International License, which permits use, sharing, adaptation, distribution and reproduction in any medium or format, as long as you give appropriate credit to the original author(s) and the source, provide a link to the Creative Commons licence, and indicate if changes were made. The images or other third party material in this article are included in the article's Creative Commons licence, unless indicated otherwise in a credit line to the material. If material is not included in the article's Creative Commons licence and your intended use is not permitted by statutory regulation or exceeds the permitted use, you will need to obtain permission directly from the copyright holder. To view a copy of this licence, visit http://creativecommons.org/licenses/by/4.0/.

\section{References}

Anderson MR, Rankin AH, Spiro B (1992) Fluid mixing in the generation of mesothermal gold mineralisation in the Transvaal Sequence, Transvaal, South Africa. Eur J Mineral 4:933-948

Bark G, Weihed P (2003) The new Lycksele-Storuman gold ore province, northern Sweden; with emphasis on the early Proterozoic Fäboliden orogenic gold deposit. In: Eliopoulos DG et al (eds) Mineral exploration and sustainable development. 7th Biennial SGA Meeting, Athens, Greece. Millpress, Rotterdam, pp 1061-1064

Bark G, Weihed P (2007) Orogenic gold in the new Lycksele-Storuman ore province, northern Sweden; the Palaeoproterozoic Fäboliden deposit. Ore Geol Rev 32:431-451

Bark G, Weihed P (2012) Geodynamic settings for Paleoproterozoic gold mineralization in the Svecofennian domain: a tectonic model for the Fäboliden orogenic gold deposit, northern Sweden. Ore Geol Rev 48:403-412

Bark G, Broman C, Weihed P (2007) Fluid chemistry of the Proterozoic hypozonal Fäboliden orogenic gold deposit, northern Sweden: evidence from fluid inclusions. GFF 129:197-210 
Bark G, Wanhainen C, Pålsson B (2013) Textural setting of gold and its implications on mineral processing: preliminary results from three gold deposits in northern Sweden. In: Erik Jonsson et al. (Eds.): Mineral deposit research for a high-tech world. 12th Biennial SGA Meeting, Uppsala, Sweden. Proceedings, Volume 1, pp 302-305

Bateman R, Hagemann S (2004) Gold mineralisation throughout about $45 \mathrm{Ma}$ of Archaean orogenesis: protracted flux of gold in the Golden Mile, Yilgarn craton, Western Australia. Mineralium Deposita 39: 536-559

Bergman Weihed J (2001) Palaeoproterozoic deformation zones in the Skellefte and Arvidsjaur areas, northern Sweden. In: Weihed P (Ed.) economic Geology Research 1999-2000. Sver Geol Unders C833: $46-68$

Beyssac O, Goffe B, Chopin C, Rouzaud J (2002) Raman spectra of carbonaceous material in metasediments: a new geothermometer. $\mathrm{J}$ Metamorph Geol 20:859-871

Billström K, Weihed P (1996) Age and provenance of host rocks and ores in the Paleoproterozoic Skellefte district, northern Sweden. Econ Geol 91:1054-1072

Björk L, Kero L (2002) Bedrock map 22I Lycksele SV, scale 1:50 000. Sveriges Geologiska Undersökning, Ai166

Böhlke JK, Kistler RW (1986) Rb-Sr, K-Ar, and stable isotope evidence for the ages and sources of fluid components of gold-bearing quartz veins in the northern Sierra Nevada Foothills metamorphic belt, California. Econ Geol 81:296-322

Bottinga Y, Javoy M (1973) Comments on oxygen isotope geothermometry. Earth Planet Sci Lett 20:250-265

Burrows DR, Spooner ETC (1989) Relationships between Archean gold quartz vein-shear zone mineralization and igneous intrusions in the Val D'Or and Timmins areas, Abitibi subprovince, Canada. Economic Geology Monograph 6:424-444

Burrows DR, Wood PC, Spooner ETC (1986) Carbon isotope evidence for a magmatic origin for Archean gold-quartz vein deposits. Nature 321:851-854

Cameron EM (1988) Archean gold: relation to granulite formation and redox zoning in the crust. Geology 16:109-112

Cameron EM (1989) Scouring of gold from the lower crust. Geology 17: 26-29

Chang Z, Large RR, Maslennikov V (2008) Sulfur isotopes in sedimenthosted orogenic gold deposits: evidence for an early timing and a seawater sulfur source. Geology 36:971-974

Claesson S, Lundqvist T (1995) Origins and ages of Proterozoic granitoids in the Bothnian Basin, central Sweden; isotopic and geochemical constraints. Lithos 36:115-140

Colvine A (1989) An empirical model for the formation of Archean gold deposits: products of final cratonization of the Superior province, Canada. Economic Geology Monograph 6:37-53

Cook NJ, Hoefs J (1997) Sulfur isotope characteristics of metamorphosed $\mathrm{Cu}-(\mathrm{Zn})$ volcanogenic massive sulfide deposits in the Norwegian Caledonides. Chem Geol 135:307-324

Cox SF (2016) Injection-driven swarm seismicity and permeability enhancement: implications for the dynamics of hydrothermal ore systems in high fluid-flux, over-pressured faulting regimes-an invited paper. Econ Geol 111:559-588

Cox SF, Sun SS, Etheridge MA, Wall VJ, Potter TF (1995) Structural and geochemical controls on the development of turbidite-hosted gold quartz vein deposits, Wattle Gully Mine, central Victoria, Australia. Econ Geol 90:1722-1746

Craw D, Upton P, Yu BS, Horton T, Chen YG (2010) Young orogenic gold mineralisation in active collisional mountains, Taiwan. Mineral Deposita 45:631-646 de Ronde CEJ, Faure K, Bray CJ, Whitford DJ (2000) Round Hill shear zone-hosted gold deposit, Macraes flat, Otago, New Zealand: evidence of a magmatic ore fluid. Econ Geol 95:1025-1048

Donnelly T, Waldron S, Tait A, Dougans J, Bearhop S (2001) Hydrogen isotope analysis of natural abundance and deuterium-enriched waters by reduction over chromium on-line to a dynamic dual inlet isotope-ratio mass spectrometer. Rapid Commun Mass Spectrom 15:1297-1303

Dragon Mining NL (2005) Annual report 2005. Perth, Australia. pp 80 Dragon Mining NL (2016) Annual report 2016. Perth, Australia. pp 95

Eilu P, Mathison C, Groves DI, Allardyce W (1999) Atlas of alteration assemblages, styles and zoning in orogenic lode-gold deposits in a variety of host rock and metamorphic settings. Geology and geophysics department, Centre for strategic mineral deposits, University of Western Australia, Publication no. 30, pp 58

Eliasson T, Sträng T (1998) Kartbladen 23H Stensele. In: Wahlgren C (Ed.) Sveriges Geologiska Undersökning, Rapporter och meddelanden 97, pp. 55-59 (In Swedish)

Eliasson T, Greiling R, Sträng T, Triumf C (2001) Bedrock map 23H Stensele NV, scale 1:50 000. Sveriges Geologiska Undersökning, Ai126

Elmer FL, White RW, Powell R (2006) Devolatilization of metabasic rocks during greenschist-amphibolite facies metamorphism. J Metamorph Geol 24:497-513

Finch EG, Tomkins AG (2017) Pyrite-pyrrhotite stability in a metamorphic aureole: implications for orogenic gold genesis. Econ Geol 112: 661-674

Frimmel HE (2008) Earths continental crustal gold endowment. Earth Planet Sci Lett 267:45-55

Gaál G, Gorbatschev R (1987) An outline of the Precambrian evolution of the Baltic Shield. Precambrian Res 35:15-52

Gaboury D (2013) Does gold in orogenic deposits come from pyrite in deeply buried carbon-rich sediments?: insight from volatiles in fluid inclusions. Geology 41:1207-1210

Gaboury D (2019) Parameters for the formation of orogenic gold deposits. Appl Earth Sci 128:124-133

Goldfarb RJ, Groves DI (2015) Orogenic gold-common or evolving fluid and metal sources through time. Lithos 233:2-26

Goldfarb RJ, Newberry RJ, Pickthorn WJ, Gent CA (1991a) Oxygen, hydrogen, and sulfur isotope studies in the Juneau Gold Belt, Southeastern Alaska: constraints on the origin of hydrothermal fluids. Econ Geol 86:66-80

Goldfarb RJ, Snee LW, Miller LD, Newberry RJ (1991b) Rapid dewatering of the crust deduced from ages of mesothermal gold deposits. Nature 354:296-298

Goldfarb RJ, Groves DI, Gardoll S (2001) Orogenic gold and geologic time: a global synthesis. Ore Geol Rev 18:1-75

Goldfarb RJ, Baker T, Dubé B, Groves DI, Hart CJR, Gosselin P (2005) Distribution, character and genesis of gold deposits in metamorphic terranes. Economic Geology 100th Anniversary Volume, pp 407 450

Goldfarb RJ, André-Mayer AS, Jowitt SM, Mudd GM (2017) West Africa: the world's premier Paleoproterozoic gold province. Econ Geol 112:123-143

Groves DI (1993) The crustal continuum model for late-Archaean lodegold deposits of the Yilgarn Block, Western Australia. Mineral Deposita 28:366-374

Groves DI, Santosh M (2016) The giant Jiaodong gold province: the key to a unified model for orogenic gold deposits? Geosci Front 7:409417

Groves DI, Phillips N, Ho SE, Houstoun SM, Standing CA (1987) Craton-scale distribution of Archean greenstone gold deposits: 
predictive capacity of the metamorphic model. Econ Geol 82:20452058

Groves DI, Goldfarb RJ, Gebre-Mariam M, Hagemann SG, Robert F (1998) Orogenic gold deposits: a proposed classification in the context of their crustal distribution and relationship to other gold deposit types. Ore Geol Rev 13:7-27

Groves DI, Goldfarb RJ, Robert F, Hart CJR (2003) Gold deposits in metamorphic belts: overview of current understanding, outstanding problems, future research, and exploration significance. Econ Geol 98:1-29

Groves DI, Santosh M, Deng J, Wang Q, Yang L, Zhang L (2019) A holistic model for the origin of orogenic gold deposits and its implications for exploration. Mineralium Deposita, published online 15 June 2019, https://doi.org/10.1007/s00126-019-00877-5

Hagemann S, Cassidy K (2000) Archean orogenic lode gold deposits. In: Hagemann, S., Brown, P., (Eds.) Gold in 2000. Rev Econ Geol 13: 9-68

Hagemann SG, Gebre-Mariam M, Groves DI (1994) Surface-water influx in shallow-level Archean lode-gold deposits in Western Australia. Geology 22:1067-1070

Hart I, Marsh S, Laurent I (1999) Svartliden - a new style of mineralisation in the Skellefte district. In: Cook NJ, Sundblad K (eds) Nordic mineral resources symposium gold '99 Trondheim. Geological Survey of Norway, Trondheim, pp 87-88

Hedenquist JW, Lowenstern JB (1994) The role of magmas in the formation of hydrothermal ore deposits. Nature 370:519-527

Heinrich CA (2007) Fluid-fluid interactions in magmatic-hydrothermal ore formation. Rev Mineral Geochem 65:363-387

Hill NJ, Jenkin GRT, Boyce AJ, Sangster CJS, Catterall DJ, Holwell DA, Naden J, Rice CM (2013) How the Neoproterozoic S-isotope record illuminates the genesis of vein gold systems: an example from the Dalradian SuperGroup in Scotland. In: Jenkin GRT, Lusty PAJ, McDonald I, Smith MP, Boyce A, Wilkinson JJ (eds) Ore deposits in an evolving earth, Special Publications 393. Geological Society, London, pp 213-247

Hodkiewicz PF, Groves DI, Davidson GJ, Weinberg RF, Hagemann SG (2009) Influence of structural setting on sulfur isotopes in Archean orogenic gold deposits, Eastern Goldfields Province, Yilgarn, Western Australia. Mineral Deposita 44:129-150

Hoefs J (2009) Stable isotope geochemistry. Springer, ISBN 978-3-54070703-5, pp 285

Jenkin GRT, Craw D, Fallick AE (1994) Stable isotopic and fluid inclusion evidence for meteoric fluid penetration into an active mountain belt: Alpine schist, New Zealand. J Metamorph Geol 12:429-444

Jia Y, Kerrich R, Goldfarb R (2003) Metamorphic origin of ore-forming fluids for orogenic gold-bearing quartz vein systems in the North American Cordillera: constraints from a reconnaissance study of $\delta^{15} \mathrm{~N}, \delta \mathrm{D}$, and $\delta^{18} \mathrm{O}$. Econ Geol 98:109-123

Kerrich R, Wyman DA (1990) The geodynamic setting of mesothermal gold deposits. An association with accretionary tectonic regimes. Geology 18:882-885

Kerrich R, Goldfarb R, Groves DI, Garwin S, Jia Y (2000) The characteristics, origins, and geodynamic settings of supergiant gold metallogenic provinces. Science in China Series D 43:1-68 (Suppl)

Kolb J, Dziggel A, Bagas L (2015) Hypozonal lode gold deposits: a genetic concept based on a review of the New Consort, Renco, Hutti, Hira Buddini, Navachab, Nevoria and the granites deposits. Precambrian Res 262:20-44

Kumpulainen RA (2009) The Bothnian Basin - its rocks, its age, its origin. Sveriges geologiska undersökning Final report Dnr: 60 $1931 / 2005$

Lahtinen R, Korja A, Nironen M (2003) Paleoproterozoic orogenic evolution of the Fennoscandian shield at 1.92-1.77 Ga with notes on the metallogeny of $\mathrm{FeOx}-\mathrm{cu}-\mathrm{au}, \mathrm{VMS}$, and orogenic gold deposits. In: Eliopoulos DG et al (eds) Mineral exploration and sustainable development. Millpress, Rotterdam, pp 1057-1060

Lahtinen R, Korja A, Nironen M (2005) Paleoproterozoic tectonic evolution. In: Lehtinen M, Nurmi PA, Rämö OT (eds) Precambrian geology of Finland - key to the evolution of the Fennoscandian shield. Elsevier Science, Amsterdam, pp 481-531

Lappland Goldminers AB (2012) Annual report 2012. Lycksele, Sweden. pp 72

Large RR, Maslennikov V, Robert F, Danyushevsky LV, Chang Z (2007) Multistage sedimentary and metamorphic origin of pyrite and gold in the giant Sukhoi Log deposit, Lena gold province, Russia. Econ Geol 102:1232-1267

Large RR, Danyushevsky L, Hollit C, Maslennikov V, Meffre S, Gilbert S, Bull S, Scott R, Emsbo P, Thomas H, Singh B, Foster J (2009) Gold and trace element zonation in pyrite using a laser imaging technique: implications for the timing of gold in orogenic and Carlin-style sediment-hosted deposits. Econ Geol 104:635-668

Large RR, Bull SW, Maslennikov VV (2011) A carbonaceous sedimentary source-rock model for Carlin type and orogenic gold deposits. Econ Geol 106:331-358

Laznicka P (1999) Quantitative relationships among giant deposits of metals. Econ Geol 94:455-474

Lisitsin VA, Pitcairn IK (2015) Orogenic gold mineral systems of the Western Lachlan Orogen (Victoria) and the Hodgkinson Province (Queensland): crustal metal sources and cryptic zones of regional fluid flow. Ore Geol Rev 76:280-295

Loucks RR, Mavrogenes JA (1999) Gold solubility in supercritical hydrothermal brines measured in synthetic fluid inclusions. Science 5423:2159-2163

Lüders V, Klemd R, Oberthür T, Plessen B (2015) Different carbon reservoirs of auriferous fluids in African Archean and Proterozoic gold deposits? Constraints from stable carbon isotopic compositions of quartz-hosted $\mathrm{CO}_{2}$-rich fluid inclusions. Mineral Deposita 50:449 454

Lundqvist T (1987) Early Svecofennian stratigraphy of southern and central Norrland, Sweden, and the possible existence of an Archaean basement west of the Svecokarelides. Precambrian Res 35:343-352

Lundqvist T (1990) Description to bedrock map of the Västernorrland county. Sveriges Geologiska Undersökning. Serie Ba. Översiktskartor med beskrivningar 31, pp 429

Lundström H (1998) Metasedimentary rocks in the district of Storuman, Västerbotten. Göteborg University, Department of Earth Sciences, MSc thesis, B163, pp 44

Matsuhisa Y, Goldsmith JR, Clayton RN (1979) Oxygen isotopic fractionation in the system quartz-albite-anorthite-water. Geochim Cosmochim Acta 43:1131-1140

Maynard J, Prichard HM, Lord RA, Ixer RA, Wright IP, Pillinger CT, Williams N, McConville P, Boyce AJ, Fallick AE (1997) Sulphur isotope study of $\mathrm{Ni}-\mathrm{Fe}-\mathrm{Cu}$ mineralisation in the Shetland ophiolite. Transactions of the Institution of Mining and Metallurgy. (Sect. B, Appl. Earth Sci) 106:B215-B226

McConville P, Boyce AJ, Fallick AE, Harte B, Scott EM (2000) Sulfur isotope variations in diagenetic pyrite from core plug to submillimetre scales. Clay Miner 35:303-311

McCuaig T, Kerrich R (1998) P-T-t-deformation-fluid characteristics of lode gold deposits: evidence from alteration systematics. Ore Geol Rev 12:381-453

Molnar F, Mänttäri I, O'Brien H, Lahaye Y, Pakkanen L, Johanson B, Käpyaho A, Sorjonen-Ward P, Whitehouse M, Sakellaris G (2016) Boron, sulfur and copper isotope systematics in the orogenic gold 
deposits of the Archaean Hattu schist belt, eastern Finland. Ore Geol Rev 77:133-162

Nesbitt BE, Muehlenbachs K, Murrowchick JB (1989) Genetic implications of the stable isotope characteristics of mesothermal Au deposits and related $\mathrm{Sb}$ and $\mathrm{Hg}$ deposits in the Canadian Cordillera. Econ Geol 84:1489-1506

Nironen M (1997) The Svecofennian Orogen: a tectonic model. Precambrian Res 86:21-44

Ohmoto H (1986) Stable isotope geochemistry of ore deposits. Rev Mineral 16:491-559

Ohmoto H, Goldhaber MB (1997) Sulfur and carbon isotopes. In: Barnes HL (ed) Geochemistry of hydrothermal ore deposits, 3rd edn. Wiley, New York, pp 435-486

Ohmoto H, Rye RO (1979) Isotopes of sulfur and carbon. In: Geochemistry of hydrothermal ore deposits, 2nd ed. Holt Rinehart and Winston, New York

Pasteris J, Wopenka B (1991) Raman spectra of graphite as indicators of degree of metamorphism. Can Mineral 29:1-9

Pattrick RAD, Boyce A, MacIntyre RM (1988) Gold and silver mineralization at Tyndrum, Scotland. Mineral Petrol 38:61-76

Phillips GN, Powell R (2009) Formation of gold deposits: review and evaluation of the continuum model. Earth Sci Rev 94:1-21

Phillips GN, Powell R (2010) Formation of gold deposits: a metamorphic devolatilization model. J Metamorph Geol 28:689-718

Pili É, Kennedy BM, Conrad ME, Gratier JP (2011) Isotopic evidence for the infiltration of mantle and metamorphic $\mathrm{CO}_{2}-\mathrm{H}_{2} \mathrm{O}$ fluids from below in faulted rocks from the San Andreas Fault system. Chem Geol 281:242-252

Pitcairn IK (2011) Background concentrations of gold in different rock types. Appl Earth Sci 120:31-38

Pitcairn IK, Teagle DAH, Craw D, Olivo GR, Kerrich R, Brewer TS (2006) Sources of metals and fluids in orogenic gold deposits: insights from the Otago and Alpine Schists, New Zealand. Econ Geol 101:1525-1546

Pitcairn IK, Olivo GR, Teagle DAH, Craw D (2010) Sulfide evolution during prograde metamorphism of the Otago and Alpine Schists, New Zealand. Can Mineral 48:1267-1295

Ramsay WRH, Bierlein FP, Arne DC, Van den Berg AHM (1998) Turbidite-hosted gold deposits of Central Victoria, Australia: their regional setting, mineralising styles, and some genetic constraints. Ore Geol Rev 13:131-151

Ridley J, Diamond L (2000) Fluid chemistry of orogenic lode gold deposits and implications for genetic models. Society of Economic Geologists Reviews 13:141-162

Ridley J, Groves DI, Knight JT (2000) Gold deposits in amphibolite and granulite facies terranes of the Archean Yilgarn Craton, Western Australia: evidence and implications of synmetamorphic mineralization. Rev Econ Geol 11:265-290

Robinson BW, Kusakabe M (1975) Quantitative preparation of $\mathrm{SO}_{2}$ for ${ }^{34} \mathrm{~S} /{ }^{32} \mathrm{~S}$ analysis from sulfides by combustion with cuprous oxide. Anal Chem 47:1179-1181

Rudnick RL, Gao S (2003) Composition of the continental crust. In: Holland HD, Turekian KK (eds) Treatise on geochemistry, Chapter 3. 01, pp 1-64 ISBN 978-0-08-043751-4

Rutland RWR, Kero L, Nilsson G, Stoelen LK (2001) Nature of a major tectonic discontinuity in the Svecofennian province of northern Sweden. Precambrian Res 112:211-237

Rye RO (1993) The evolution of magmatic fluids in the epithermal environment: the stable isotope perspective. Econ Geol 88:733-753

Saalmann K, Mänttäri I, Ruffet G, Whitehouse MJ (2009) Age and tectonic framework of structurally controlled Palaeoproterozoic gold mineralization in the Häme belt of southern Finland. Precambrian Res 174:53-77
Schlöglova K, Gordon C, Hanes R, Ask H, Broman C (2013) Svartliden gold mine: shear zone and BIF-hosted orogenic gold deposit, Gold Line, northern Sweden. In: Erik Jonsson et al. (Eds.): Mineral deposit research for a high-tech world. 12th Biennial SGA Meeting, Uppsala, Sweden. Proceedings, volume 3, pp 1193-1196

Seal RR (2006) Sulfur isotope geochemistry of sulfide minerals. Reviews in Mineralogy \& Geochemistry 61:633-677

Sharp ZD (1990) A laser-based microanalytical method for the in situ determination of oxygen isotope ratios of silicates and oxides. Geochim Cosmochim Acta 54:1353-1357

Shen P, Pan H, Zhu H (2016) Two fluid sources and genetic implications for the Hatu gold deposit, Xinjiang, China. Ore Geol Rev 73:298312

Sibson RH, Robert F, Poulsen KH (1988) High-angle reverse faults, fluidpressure cycling, and mesothermal gold-quartz deposits. Geology 16:551-555

Söderlund U, Elming S-Å, Ernst RE, Schissel D (2006) The Central Scandinavian Dolerite Group - protracted hotspot activity or backarc magmatism? Constraints from U-Pb baddeleyite geochronology and Hf isotopic data. Precambrian Res 150:136-152

Spence-Jones CP, Jenkin GRT, Boyce AJ, Hill NJ, Sangster CJS (2018) Tellurium, magmatic fluids and orogenic gold: an early magmatic fluid pulse at Cononish gold deposit, Scotland. Ore Geol Rev 102: 894-905

Steadman JA, Large RR, Davidson GJ, Bull SW, Thompson J, Ireland TR, Holden P (2014) Paragenesis and composition of ore minerals in the Randalls BIF-hosted gold deposits, Yilgarn Craton, Western Australia: implications for the timing of deposit formation and constraints on gold sources. Precambrian Res 243:110-132

Steed GM, Morris JH (1997) Isotopic evidence for the origins of a Caledonian gold-arsenopyrite-pyrite deposit at Clontibret, Ireland. Transactions - Institution of Mining and Metallurgy. Section B: Applied Earth Science 106:109-118

Suzuoki T, Epstein S (1976) Hydrogen isotope fractionation between OH-bearing minerals and water. Geochim Cosmochim Acta 40: $1229-1240$

Taylor HP (1974) The application of oxygen and hydrogen isotope studies to problems of hydrothermal alteration and ore deposition. Econ Geol 69:843-883

Taylor HP (1980) The effects of assimilation of country rocks by magmas on ${ }^{18} \mathrm{O} /{ }^{16} \mathrm{O}$ and ${ }^{87} \mathrm{Sr} /{ }^{86} \mathrm{Sr}$ systematics in igneous rocks. Earth Planet Sci Lett 47:243-254

Thomas HV, Large RR, Bull SW, Maslennikov V, Berry RF, Fraser R, Froud S, Moye R (2011) Pyrite and pyrrhotite textures and composition in sediments, laminated quartz veins, and reefs at Bendigo Gold Mine, Australia: insights for ore genesis. Econ Geol 106:1-31

Tomkins AG (2010) Windows of metamorphic sulfur liberation in the crust: implications for gold deposit genesis. Geochim Cosmochim Acta 74:3246-3259

Tomkins AG (2013) On the source of orogenic gold. Geology 41:12551256

Tomkins AG, Grundy C (2009) Upper temperature limits of orogenic gold deposit formation: constraints from the granulite-hosted Griffin's Find Deposit, Yilgarn Craton. Econ Geol 104:669-685

Vilor NV (1983) Gold in black shales. Geochem Int 20:167-177

Vry J, Powell R, Golden KM, Petersen K (2010) The role of exhumation in metamorphic dehydration and fluid production. Nat Geosci 3:3135

Wagner T, Boyce AJ, Jonsson E, Fallick AE (2004) Laser microprobe sulfur isotope analysis of arsenopyrite: experimental calibration and application to the Boliden $\mathrm{Au}-\mathrm{Cu}-\mathrm{As}$ massive sulfide deposit. Ore Geol Rev 25:311-325 
Wasström A (1993) The Knaften granitoids of Västerbotten county, northern Sweden. In Lundqvist T (Ed.) Radiometric dating results. Sver Geol Unders C823:60-64

Wasström A (1996) U-Pb zircon dating of a quartz-feldspar porphyritic dyke in the Knaften area, Västerbotten county, northern Sweden. In: Lundqvist T (Ed.) Radiometric dating results 2. Sver Geol Unders C828:34-40

Weatherley DK, Henley RW (2013) Flash vaporization during earthquakes evidenced by gold deposits. Nat Geosci 6:294-298

Wedepohl KH (1995) The composition of the continental crust. Geochim Cosmochim Acta 7:1217-1232

Weihed P, Bergman J, Bergström U (1992) Metallogeny and tectonic evolution of the early Proterozoic Skellefte district, northern Sweden. Precambrian Res 58:143-167

Weihed P, Billström K, Persson PO, Bergman Weihed J (2002a) Relationship between $1.90-1.85$ Ga accretionary processes and 1.82-1.80 Ga oblique subduction at the Karelian craton margin, Fennoscandian Shield. GFF 124:163-180

Weihed P, Bergman Weihed J, Sorjonen-Ward P, Matsson B (2002b) Post-deformation, sulfide-quartz vein hosted gold ore in the footwall alteration zone of the Palaeoproterozoic Långdal VHMS deposit, Skellefte District. GFF 124:201-210
Weihed P, Arndt N, Billström K, Duchesne J-C, Eilu P, Martinsson O, Papunen H, Lahtinen R (2005) 8: Precambrian geodynamics and ore formation: the Fennoscandian Shield. Ore Geol Rev 27:273-322

White AJR, Waters DJ, Robb LJ (2015) Exhumation-driven devolatilization as a fluid source for orogenic gold mineralization at the Damang deposit, Ghana. Econ Geol 110:1009-1025

Wilson MR, Hamilton PJ, Fallick AE, Aftalion M, Michard A (1985) Granites and early Proterozoic crustal evolution in Sweden: evidence from $\mathrm{Sm}-\mathrm{Nd}, \mathrm{U}-\mathrm{Pb}$ and $\mathrm{O}$ isotope systematics. Earth Planet Sci Lett 72:376-388

Xue Y, Campbell IH, Ireland TR, Holden P, Armstrong R (2013) No mass-independent sulfur isotope fractionation in auriferous fluids supports a magmatic origin for Archean gold deposits. Geology 41:791-794

Yardley BWD, Cleverley JS (2015) The role of metamorphic fluids in the formation of ore deposits. In: Jenkin GRT, Lusty PAJ, McDonald I, Smith MP, Boyce AJ, Wilkinson JJ (eds) Ore deposits in an evolving earth. Geological Society, London, Special Publication 393, pp 117134

Publisher's note Springer Nature remains neutral with regard to jurisdictional claims in published maps and institutional affiliations. 